\title{
Biological Sample Export Document
}

National Cancer Institute

\section{Source}

National Cancer Institute. Biological Sample Export Document. NCI Thesaurus. Code

C115635.

Records detailing the type biological specimen being exported. 